\title{
GENERIC STRUCTURE POTENTIAL OF COURSE DESCRIPTION
}

\author{
Ho Tuong Thanh ${ }^{1}$, Nguyen Thi Minh Tam*2 \\ 1. Faculty of English Language Teacher Education \\ VNU University of Languages and International Studies, Pham Van Dong, Cau Giay, Hanoi, Vietnam \\ 2. Faculty of Linguistics and Cultures of English-Speaking Countries \\ VNU University of Languages and International Studies, Pham Van Dong, Cau Giay, Hanoi, Vietnam
}

Received 14 July 2020

Revised 14 August 2020; Accepted 15 January 2021

\begin{abstract}
Generic Structure Potential (GSP), which is a "range of textual structures available within a genre" (Hasan, 1984, p. 79) was developed based on the need for a "generic structure" of a text to gain a comprehensive understanding of a genre (Halliday, 1978). Despite various research into different types of academic and promotional genres, there has been little attention given to the course description. This research seeks to unveil the GSP of course description and identify differences between formal course descriptions and online ones, analyzed based on a fourteen-element analytical framework. The findings revealed four more elements apart from those available in the original analytical framework. Most importantly, the course description was discovered to play the role of both informing and promotional, yet the former role is dominant. Regarding the difference between conventional and online descriptions, online ones were found to possess a higher number of promotional elements but still focus on informing students and promoting the course at the same time. The sequence of these elements seems to resemble the purchase decision-making process of customers significantly. On the contrary, the traditional description puts major emphasis on the informative purpose and shows negligence to the promotional aspects.
\end{abstract}

Key words: GSP, course description, traditional courses, online courses

\section{Introduction}

In recent years, the adaptation of the free market model into school administration, which is known as the marketization of education (Kwong, 2000), seems to be on the rise. This trend occurs due to the reduced financial assistance from the government. As financial independence is being upheld in academic institutions, their original mission of human development and knowledge creation might be neglected and negotiated with profit-making through increasing the number of student intake and producing "marketable products" (Askehave, 2007; Mautner, 2005). This phenomenon can also be felt in the discursive practices with the realization of Fairclough (1995) when analysing university prospectus. These institutions appear to focus extensively on "selling" the course to potential students in an increasingly competitive market.

In this study, the researcher focuses on investigating the genre of course description, an

\footnotetext{
* Corresponding author. Tel.: 84-989669422

Email: tamntm1982@vnu.edu.vn
}

academically produced product. Course description, without a doubt, is important as it serves as one of the main channels of introducing students to suitable courses. Numerous research stated that the choice of courses has a determining impact on students' subsequent studying and career commitment (Kuh et al., 2006; Bożykowski et al., 2014; Zajac \& Komendant-Brodowska, 2018). The wrong course choice has been pinpointed as one of the main reasons behind school drop-out (Yorke, 1999; Gibson \& Walters, 2002; Borzovs, Niedrite \& Solodovnikova, 2016). In addition, the course content and structure is deemed as a decisive criterion for choosing an institution (Maringe, 2006; Bhardwa, 2018). Therefore, a high-quality course description can assist students in selecting the most suitable course and ensure students have a fulfilling studying period.

Despite the importance of course descriptions on students' choice of studying and future career, there has been little attention given to this type of genre. With a view to filling in this gap to a certain extent, this study aims at examining the GSP of English course descriptions, through analysing course descriptions from a formal academic institution and an online course provider. To 
achieve the two objectives, which are, first, revealing the generic patterns of course descriptions and second, highlighting the major differences between a traditional description and an online one, two research questions were proposed:

1. What is the generic structure potential of the course description?

2. How is the generic structure potential of the conventional university course description different from that of the online course description?

\section{Literature review}

\subsection{Genre and genre analysis}

Genre is commonly known as types of texts, and these types of texts have distinctive features because "they do different things" (Callaghan, Knapp \& Noble, 1993, p. 7). Genre can be defined as a "staged, goal-oriented, purposeful activity in which speakers engage in as members of our culture" (Martin, 1984, p. 25).

The notion of genre can be viewed from two perspectives: from a linguistic viewpoint and based on its social and communicative purposes. From the former viewpoint, genre is defined as "a typified form of discourse or way of organizing or structuring discourse" (Chapman, 1994, p. 352) and a social strategy "embodied in the form of discourse" (Coe \& Friedman, 1998, p. 41). A genre consists of a number of obligatory and optional structural elements (Hasan, as cited in Halliday
\& Hasan, 1989). It is these compulsory elements that distinguish one type of genre from another thanks to their relation to the range of genre classification.

Apart from being defined as a type of discourse, a genre can also be viewed based on its communicative aims (Hasan, as cited in Halliday \& Hasan, 1989). A more detailed working definition of genre was proposed by Swales (1990), in which genre is described as "a class of communicative events, the members of which share some set of communicative purposes" (p. 45). These communicative aims then determine the structure of the genre and the choice of content and style, which is similar to the definition proposed by Dudley-Evans (1994) that defining genre as "a means of achieving a communicative goal that has evolved in response to particular rhetorical needs". From a more social perspective, as aforementioned, genre is considered a "staged, goal-oriented, purposeful activity in which speakers engage in as members of our culture" (Martin, 1984, p. 25). In this definition, a genre is "staged" as it is comprised of several organization structures, "goal-oriented" because it has specific goals and "social" because of its presence as a communication medium of community members (Martin, Christie \& Rothery, 1987). The association of different social processes with the types of genre can be summarized in the figure below by Knapp and Watkins (1994, p. 26).

\section{Figure 1}

Classification of Genres (Knapp \& Watkins, 1994, p. 26)

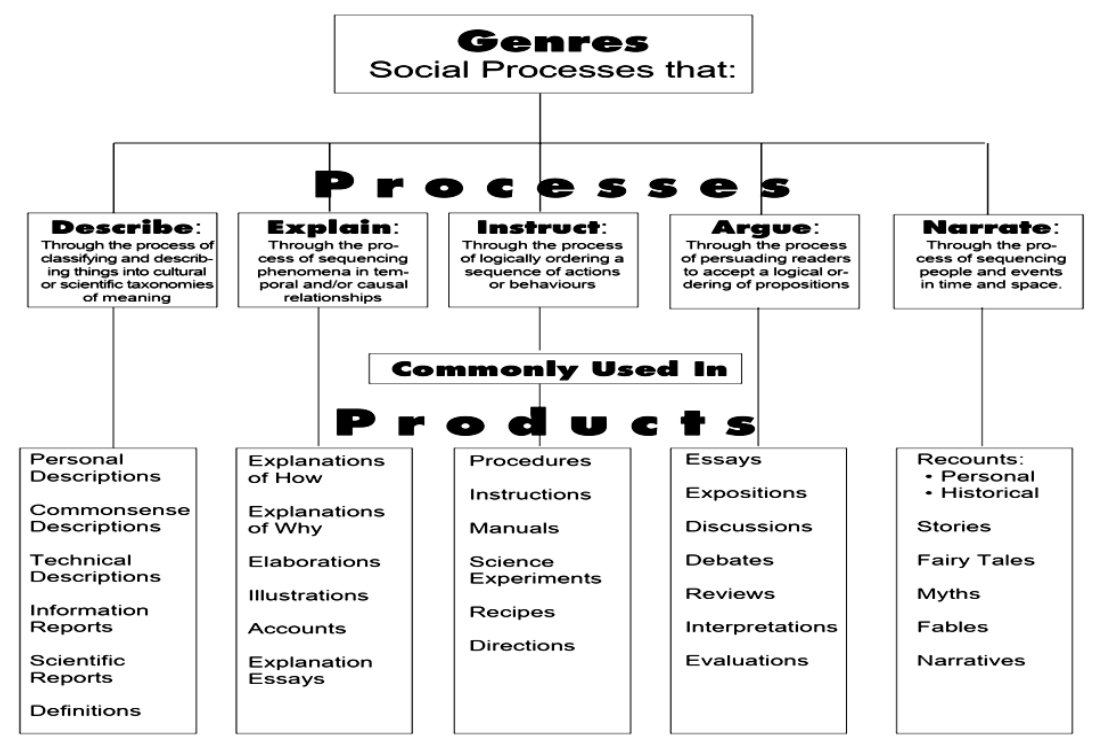


Genre analysis is commonly deemed as a "situated linguistic behaviour" (Bhatia, 2002, p. 4). Three of the most commonly used approaches for analysing genre are the New Rhetoric, English for Specific Purposes (ESP), and the Systemic Functional Linguistics (SFL) approaches (Bawarshi \& Reiff, 2010; Hyland, 2002; Hyon, 1996).

These three approaches share the same notion of the link between linguistic actions and their function and social context. However, it is the focus of each approach that distinguishes them. While the New Rhetoric approach places focus on the social actions surrounding the genre, the emphasis of ESP research is the discourse structure. On the other hand, the SFL approach attempts to reveal the grammatical characteristics and discourse structure of a genre and how they are related to their social functions (Yunick, 1997). Another significant difference between the SFL and the ESP approach is the selection of analytical data. While the so-called "pre-genre" is the concentration of SFL scholars such as explanations and reports (Johns, 2012), typical genres of ESP research are the community-linked ones such as literature review, research articles, job applications. This different choice of focus explains the micro-level analysis of the ESP approach compared to the macro-level analysis of the SFL approach (Bawarshi \& Reiff, 2010).

Among these three approaches, two models emerged as essential to analysing genre, namely the Move Structure of the ESP approach and the Generic Structure Potential of the SFL approach. In the former model, the functional goals of the text elements define the "moves" in the text, and then each "move" is then further divided into "steps". Therefore, a genre will be comprised of a fixed sequence of moves. On the other hand, the Generic Structure Potential (GSP) model was proposed in Hasan and Halliday (1989) with a view to investigating the fundamental and elective structural elements of a specific type of text, then formulate a detailed description of the text genre.

\subsection{Generic Structure Potential}

In 1978, in an attempt to investigate the nature and functions of genre, in his work, Halliday argued that "in order to give a complete characterisation of texture, we should also have to make reference to 'generic structure', the form that a text has as a property of its genre" (p. 61). Following this argument,
Hasan (1984, p. 79) defined genre as a "range of textual structures available within a range". In 1989, Hasan (as cited in Halliday \& Hasan 1989) gave a more systematic description of generic analysis, known as the generic structure potential, a fundamental concept of the SFL approach.

GSP was developed based on the notion of Contextual Configuration, the values of the variables, namely the field, the mode and the tenor that "permits statements about the text structures" (Halliday \& Hasan, 1989). A Contextual Configuration can provide predictions about the following elements of a text structure:

(1) Obligatory elements - What elements must occur?

(2) Optional elements - What elements may occur?

(3) Sequencing of elements - What arrangement of elements is obligatory and optional?

(4) Iteration - How often may the elements occur?

As shown above, GSP consists of obligatory, optional and iterative elements that together form a fixed sequence. Obligatory elements can be deemed as the main components of a genre and distinguish one genre for the others. Optional elements, on the other hand, only appear in certain cases and are predictable. Lastly, iterative elements are used to signify the repetitive occurrence of any element (Hasan, 1979).

Following is the result of a study by Halliday and Hasan (1989) to analyse the GSP of shop transaction.

\section{Figure 2}

GSP of Shop Transaction (Halliday \& Hasan, 1989, p. 64)

$$
\begin{gathered}
\curvearrowleft \quad \bumpeq \\
{\left[(\mathrm{G}) \cdot(\mathrm{SI})^{\wedge}\right]\left[(\mathrm{SE} \bullet)\left\{\mathbf{S R}^{\wedge} \mathbf{S C}^{\wedge}\right\} \wedge \mathbf{S}^{\wedge}\right] \mathbf{P}^{\wedge} \mathbf{P C}\left({ }^{\wedge} \mathrm{F}\right)}
\end{gathered}
$$

The pattern above shows the nine elements in any shop transaction namely Greeting $(\mathrm{G})$, Sale Initiation (SI), Sale Enquiry (SE), Sale Request (SR), Sale Compliance (SC), Sale (S), Purchase (P), Purchase Closure (PC) and Finis (F).

- Among these elements, SR, SC, S, P and $\mathrm{PC}$ are obligatory ones and appear in every conversation. 
- The remaining elements, namely G, SI, SE, $\mathrm{F}$ are optional. They can only be found in some conversations.

- Elements SE, SR and SC are iterative and can be repeated in some cases.

- Some elements such as G and SI can switch places into $(\mathrm{G})^{\wedge}(\mathrm{SI})$ or $(\mathrm{SI})^{\wedge}(\mathrm{G})$.

- Some elements have already maintained a fixed sequence. For example, F will always occur at the end of the conversation.

Besides the investigation into shop transaction GSP by Halliday and Hasan (1989), the GSP model has been utilized to develop the discourse structure of several types of genre, both informative and promotional. Paltridge (1993) attempted to construct the GSP of research introduction. He established an eightelement framework, among which only two elements, namely "the previous research" and "purpose of study" were found to be obligatory to a research introduction. Osat (2012) focused his study on the genre of entrepreneurship article. It was found that the two obligatory elements in this particular type of genre also correspond with Paltridge's (1993) findings. However, the major difference was the gap in the number of optional elements, eleven elements compared to the recorded six elements in Paltridge (1993). In this study, the categorization of elements into obligatory and optional elements are employed as the statusbased framework to analyze the elements of course descriptions.

\subsection{Course description as a type of genre}

A course description is commonly known as a descriptive passage at the beginning of any course introduction. It is mainly used to introduce the major course content and other essential information. A course description, originally, can fall into the academic introduction genre as it provides important information about the course, such as the focus, activities and assignments to prospective students. This aim of the course description, in this way, is similar to the communicative goal of an academic introduction, namely introducing any academically written or spoken event (Bhatia, 1997) such as the introduction of research article introduction (Swales, 1990).

A course description might also belong to the promotional genre because it can be used to attract prospective students. This goal can be recognized through the inclusion of students' reviews and positive comments on the course. In some cases, the appearance of promotional elements can be so overwhelming that it can override the original communicative goal, which is predicted by Swales (1990) when examining the research article introduction.

In short, a course description reserves two main communicative goals: informing and promotional.

No research on GSP of course description has been conducted so far. However, studies of the generic features of university-related texts could be found, including a study of the generic features of "Why choose us?" text in university websites conducted by Yang (2013) and an analysis of the promotional genre in the academic setting was also found in the study into university brochures by Osman (2008). Compared to the framework by Yang (2013), the framework designed by Osman (2008) contained ten moves, with moves fulfilling similar functions of evoking response from readers but with different names like "soliciting response from the audience" (Osman, 2008) and "end with suggestions" (Yang, 2013). Further study is the generic analysis of international students' prospectus by Askehave (2007). Based on the findings, it can be concluded that the obligatory "move repertoire" in all the surveyed universities contain the following moves: identification of sender, description of university, description of courses/degrees, description of destination, providing practical information - fast facts and providing contact information. The GSP analysis of course description is not found in any previous research, but the findings of the studies reviewed above provide an overview of the potential functions that different elements of any academic and promotional university texts may probably fulfill. The analytical framework of course description elements based on their functions in the texts could be constructed based on these studies.

\section{The study}

\subsection{The corpus}

The corpora of this study comprise a total of forty course descriptions, with twenty descriptions from faculty $\mathrm{Y}$ of university $\mathrm{X}$, namely the university corpus, and twenty 
descriptions from a privately run online course provider named A, namely the online corpus. The main criteria for choosing these two sources are their reputation. University $\mathrm{X}$ is one of the highly ranked education institutions nation-wide, while platform $\mathrm{A}$ has been in the online course provider ranking table for years. Regarding the selection of data, the course descriptions from website A were chosen based on their degree of representativeness, which refers to the similarity of course content and field of study between the two sources.

\subsection{Analytical framework}

The function-based analytical framework

Table 1

Proposed Elements of the Course Description for categorizing elements of course description in this study is a combination of elements found in the following corpora: the "Why choose us?" section in university websites (Yang, 2013), international students' prospectus (Askehave, 2007), university brochures (Osman, 2008), research article introduction (Paltridge, 1993), and introduction in entrepreneurship research articles (Osat, 2012). An element named "Others" was also added to represent the unavailable elements in the proposed framework. (Please refer to Appendix 2 for a specific example of each element)

\begin{tabular}{|c|c|c|c|}
\hline No. & Elements & Description & Short forms \\
\hline 1 & Welcoming remark & \multirow{2}{*}{$\begin{array}{l}\text { Refers to the welcoming message from the course instructor } \\
\text { Introduces some general knowledge about the course } \\
\text { content }\end{array}$} & $\mathrm{W}$ \\
\hline 2 & Background information & & BI \\
\hline 3 & Topic centrality & Emphasizes the importance of the taught content & $\mathrm{T}$ \\
\hline 4 & Indicating a gap & $\begin{array}{l}\text { Points out the lack of the taught content in the standard } \\
\text { educational curriculum }\end{array}$ & IG \\
\hline 5 & Claim & $\begin{array}{l}\text { Refers to the writer's evaluation of the presented situation } \\
\text { or fact }\end{array}$ & CA \\
\hline 6 & Establishing credentials & $\begin{array}{l}\text { Focuses on the course instructor's qualifications (e.g, } \\
\text { working experience, successful students, awards, etc.) }\end{array}$ & EC \\
\hline 7 & $\begin{array}{l}\text { Ensuring teaching } \\
\text { quality }\end{array}$ & $\begin{array}{l}\text { Describes the teacher-responsibility-related elements that } \\
\text { will contribute to a motivating learning environment }\end{array}$ & EQ \\
\hline 8 & $\begin{array}{l}\text { Indicating the value of } \\
\text { the service }\end{array}$ & $\begin{array}{l}\text { Refers to the entry requirements, fees and duration of the } \\
\text { course }\end{array}$ & I \\
\hline 9 & $\begin{array}{l}\text { Endorsing the value of } \\
\text { the service }\end{array}$ & Refers to statements describing the course objectives & $\mathrm{E}$ \\
\hline 10 & Describing the service & $\begin{array}{l}\text { Refers to statements about the course content and the } \\
\text { teaching and learning methods }\end{array}$ & $\mathrm{D}$ \\
\hline 11 & $\begin{array}{l}\text { Offering attractive } \\
\text { incentives }\end{array}$ & $\begin{array}{l}\text { Describes the financial support or reward-related elements } \\
\text { which motivate students to apply }\end{array}$ & OI \\
\hline 12 & Soliciting responses & $\begin{array}{l}\text { Ends the description with invitations for enrolment or } \\
\text { further questions about the course }\end{array}$ & $\mathrm{S}$ \\
\hline 13 & Closing remark & $\begin{array}{l}\text { Refers to the last few words from the course descriptor to } \\
\text { end the description }\end{array}$ & $\mathrm{C}$ \\
\hline 14 & Others & Elements that are not addressed above & $\mathrm{O}$ \\
\hline \multicolumn{2}{|c|}{$\begin{array}{l}\text { As regards the status-based categorization } \\
\text { of elements into obligatory and optional } \\
\text { elements, Hasan (1984) states that obligatory } \\
\text { elements are those that must occur, not those } \\
\text { that occur in all texts of the genre. The modal } \\
\text { verb "must" indicates a very high chance of } \\
\text { elements occurring in texts, not a } 100 \% \\
\text { absolute occurrence of the element. Therefore, } \\
\text { in authentic texts analysis, a certain range of } \\
\text { variation in analysis should be allowed to avoid } \\
\text { any extreme overgeneralization about all texts } \\
\text { in the genre. Such a variation range was needed }\end{array}$} & $\begin{array}{l}\text { for any uncertainty about th } \\
\text { presence of the elements in ev } \\
\text { since no corpora can ever } \\
\text { possible in the genre. When } \\
\text { corpora with a huge number } \\
\text { variation range in the analysis } \\
\text { very small, even asymptotic to z } \\
\text { To be more specific, in the } \\
\text { study, sometimes, if the cou } \\
\text { writers and audience share the } \\
\text { (e.g., teachers and students in th } \\
\text { the same university, etc.), e }\end{array}$ & $\begin{array}{l}\text { absence or } \\
\text { y single text } \\
\text { er all texts } \\
\text { xploring the } \\
\text { f texts, the } \\
\text { ould become } \\
\text { orpora of this } \\
\text { description } \\
\text { ame contexts } \\
\text { same faculty, } \\
\text { nent ellipsis }\end{array}$ \\
\hline
\end{tabular}


might happen. That is, due to the shared assumption among people in those contexts that those elements could be already well known, the presence of those elements might be redundant. Accordingly, that some elements are missing does not mean that they have no function at all in the course description. In the same way, for some specific reasons in certain contexts, some very informal elements might be attached to the course description - an academic genre as discussed in 2.3. The attachment of these elements to the course description may mean that, besides the major aim of describing the course, the teacher wants to additionally communicate some very personal message to his/her students, which is not a typical feature of such an academic genre as course description (or in other words, the convention is that those elements should not be where they are seen in the present academic text). To ensure the representativeness of the data in this academic genre, the informal elements with very low occurrence (say less than $2 \%, 5 \%$, or $10 \%$ ) were not further processed.

The analytical framework for labeling obligatory and optional elements is summarized in Table 2.

Table 2

The Status of the Elements

\begin{tabular}{cc}
\hline Occurrence in the corpora & Status of elements \\
$\geq 90 \%$ of texts & obligatory \\
$<90 \%, \geq 10 \%$ of texts & optional \\
$<10 \%$ of texts & N/A \\
\hline
\end{tabular}

\subsection{Data analysing procedure}

The analysing procedure is comprised of four main steps.

Firstly, each course description in both the university corpus and the online corpus was numbered, and elements were functionally classified based on the proposed fourteenelement framework in Table 1 . To ensure the reliability of the analysis, two coders worked independently in the coding process, resulting in two independent lists of coded elements. The two element-coding lists were then compared; and in any case of differences in the coding results, the coders discussed carefully how the elements should be categorized and labelled. The coding process results went through the supervision of an experienced functional linguist whose expertise was genre analysis before the final results were confirmed.

Secondly, the status of each element (obligatory or optional) was categorized according to their occurrence, based on the analytical framework in Table 2. As the number of course descriptions in the corpora collected for this study was quite small (only 40 for two corpora), a ten-percent variation range in element categorization was allowed in order to avoid any extreme overgeneralization about the status of the elements in course description in general. That is, an element was deemed obligatory when it was identified in at least $90 \%$ of the total corpus, while elements with at least $10 \%$ occurrence frequency in all the texts were declared optional. Elements with the occurrence of less than $10 \%$ were not further analyzed and labelled. Any elements that were repeated in the text and at different sections is regarded as reiterative. The generic patterns of the corpus were reached. These data were the answer to the first research question.

Thirdly, the results from the second steps were gathered to identify the differences in the element occurrences between the two groups of data: conventional course description and online course description.

Finally, the status of the elements and their sequencing in relation to other elements were declared. The GSP of course descriptions in each corpus, conventional course description in the university corpus and online course description in the online corpus, was constructed. The second research question was now answered.

\section{Findings and Discussion}

\subsection{General findings}

The preliminary analysis identified four new more elements, namely: (Please refer to Appendix 2 for a specific example of each element)

- Social expectation (SE) which describes the course expectation to certain groups of students

- Selling point (SP) which refers to promises of exceptional outcome from the description writer

- Demonstrating understanding (DU) which describes the expected audience's reaction to the taught content 
- Addressing needs (A) which outlines specific types of students with different needs

Another noticeable finding is the presence of several elements in a single sentence. The sentence below, which is packed with four elements, is an example.

"You are about to learn powerful, expertlevel (Element 7 - Ensuring teaching quality) skills (Element 10 - Describing the service) to understand and speak about most problems of international politics (Element 9 Endorsing the value of the service) like a confident expert even without prior university education in Politics or International Relations. (Element 14 Selling point)" - International Politics Mastery: Level of Analysis.

Generally speaking, the number of elements in the corpus is diverse. The average number of elements present in the corpus is 13.82 . Regarding the difference between the online and traditional descriptions, the average number of the former (10.7) is more than three times higher than that of the latter (3.2). The number of obligatory (3) and optional elements (12) of the online descriptions also outnumbers the traditional descriptions, 1 and 9, respectively. This noticeable gap suggests that the online description writers tend to include more information types than the traditional ones.

In general, the potential elements of the course descriptions can be summarized as below.

- The sole obligatory element of the course description is the "Describing the service", which presents the major course content. Due to its utmost importance, it usually takes up to a few paragraphs and can appear at several locations in the descriptions. In descriptions with a modest number of elements, it is likely to appear at the beginning of the description, usually after the optional element "Background

\section{Chart 1}

Frequency of Elements in Course Descriptions From Faculty Y, University X

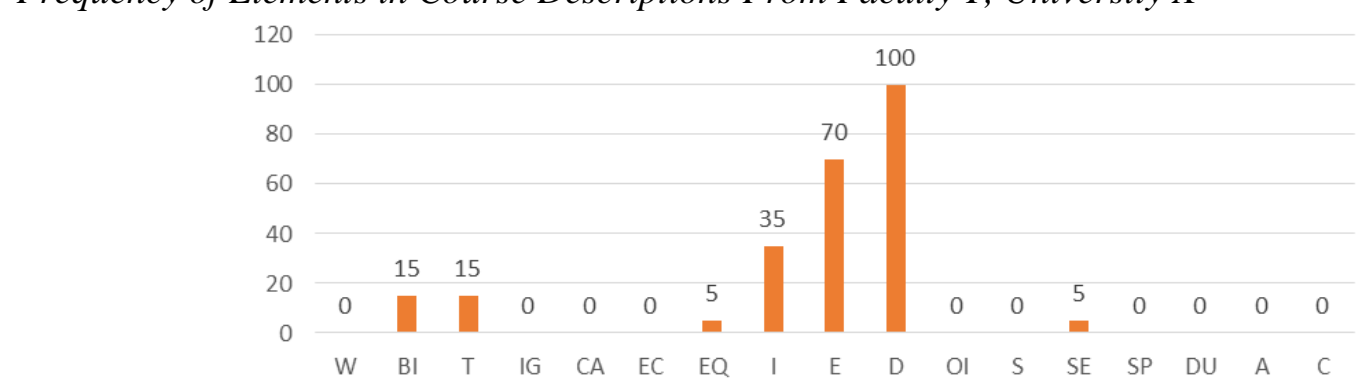

information". In addition, this element itself can serve as a full course description. However, in descriptions rich in information and elements, this element is mentioned in several sections and in company with two other elements, namely "Endorsing the value of the service" and "Ensuring the teaching quality".

- The optional elements in the course descriptions are quite diverse and cover different types of information. Some elements that record high frequency rate and have proved their importance are the "Background information", "Ensuring teaching quality" and "Endorsing the value of the service". While the first element is commonly found at the beginning of the introduction, the second and third element mostly accompany the element "Describing the service" and might even serve as a section within this element. Another element that is recognizable in the corpus is the "Topic centrality" which often appears in the sentences following the "Background information".

- An element can only be declared reiterative should the content be repeated in another paragraph or section of the text. In the corpus, the two most commonly found reiterative elements are the "Describing the service" and "Endorsing the value of the service" accounting for one fourth of the number of texts. The low rate of reiteration suggests that repetition might not be one of the course description writer's approaches to deliver their message.

\subsection{Findings about the traditional course descriptions}

The frequency rate of each element in the descriptions from faculty $\mathrm{Y}$ will be illustrated in the chart below. 
According to the chart, only seven out of a total of seventeen elements are present in the descriptions of faculty Y. This disparity suggests that these descriptions place emphasis on specific aspects such as the content of the course and the course outcome for a certain group of readers instead of including diverse types of information for a wide range of audience.

The seven elements available in the course descriptions are "Background information", "Topic centrality", "Ensuring teaching quality", "Indicating the value of the service", "Endorsing the value of the service", "Describing the service" and "Social expectation". Since the two elements with the highest frequency rate aim at introducing the course content and the course objectives, it can be concluded that the traditional course descriptions lean more toward the informing purpose rather than the promotional side.

The single obligatory element in this description is "Describing the service". This element summarizes the most essential parts of the course and is often written in a detailed and concise manner. It can be regarded as the key determining factor of the course description. In the traditional course descriptions, this element holds flexible positions and can be positioned in almost every section of the description. Furthermore, it can serve as a course description on its own.

There are four optional elements in a traditional course description, namely "Background information", "Topic centrality", "Indicating the value of the service" and "Endorsing the value of the service". The other two elements cannot obtain this status due to their limited appearance in the corpus. Out of the four optional elements, element "Endorsing the value of the service" was recorded in the highest number of texts and commonly accompanies the obligatory element. It describes the outcome after the course and gives readers a potential sense of achievement. Element "Background information", which provides some side information about the course or the course content, also holds the same frequency rate, yet its location varies in different locations. Element "Indicating the value of the service", on the other hand, describes the entry requirements of the course. These requirements are in diverse formats, ranging from students' interest “... for those interested in country-studies, especially English Study" (Literature and Communication), to students' major "It is designed for ELT and English linguistics students" (Introduction to Linguistics 1), and students' capability "There is no prerequisite other than a good command of English" (Semantics).

Reiteration can only be found in two elements in the traditional descriptions, which are "Describing the service" (D) and "Endorsing the value of the service" (E). This repetition rate indicates the preference of the description writers to emphasize the course content and course objectives. However, the writer's approach to each element differs. For element D, the course content can be separated into different parts, and then each part is placed at different sections of the description. Nevertheless, for element E, a summary of the course objectives is presented first, and then specific objectives in terms of skills, knowledge or attitude are then introduced.

\subsection{Findings about the online course descriptions}

The frequency rate of elements from the online course description is displayed in the following chart.

\section{Chart 2}

Frequency of Elements in Course Descriptions From Platform A

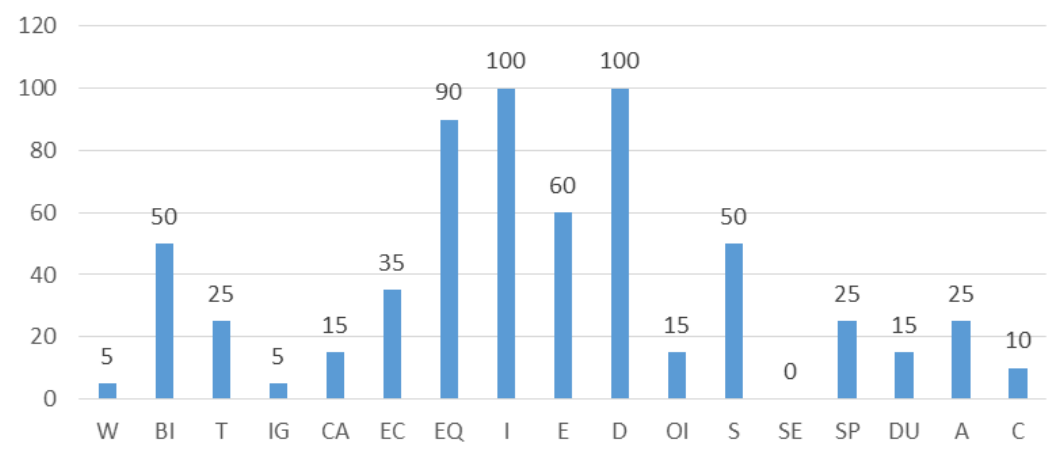


In general, the course descriptions from platform A have extensive coverage of information, with sixteen elements available out of the total seventeen. Therefore, it seems that these descriptions are obliged to convey a significantly wide range of purposes. Among these seventeen elements, only four elements including "Background information", "Indicating the value of the service", "Describing the service" and "Endorsing the value of the service" focus on informing the readers of the directly courserelated information, which indicates the predominance of promotional elements in the online course descriptions.

Elements in online descriptions also hold diverse frequency rates, with the elements "Indicating the value of the service" and "Describing the service" occupying a 100\% frequency of occurrence. On the other hand, the lowest frequency rate, from $5 \%$ to $10 \%$, can be found in the "Welcoming", "Closing" and "Indicating a gap" elements. The modest appearance of "Welcoming" and "Closing" suggests that the paragraph format is preferred by description writers rather than the letter or conversation format. Besides, the rare occurrence of "Indicating a gap", which refers to the absence of the course content from the formal curriculum, displays the writer's refraining from emphasizing the uniqueness of the course for fear of overgeneralization. It is also noticeable that the element "Social expectation" is absent from the corpus, which can be interpreted that an online course should be taken as a personal experience instead of a forceful journey.

The three obligatory elements present in the descriptions are "Describing the service", "Indicating the value of the service" and "Ensuring teaching quality". Among these three elements, the element "Ensuring teaching quality" plays the role of promoting the course, when the writers make an attempt to uphold the high quality of the course with facts, evidence and promises. On the other end of the spectrum, the informative purpose is displayed through the other two elements "Describing the service" and "Indicating the value of the service". An interesting feature of these two elements is the diversity in presentation. Instead of the common form of paragraphs, bullet points are also widely used for a clearer introduction of the course content and requirements for prospective students.

Regarding optional elements, ten out of the remaining thirteen elements obtain this status. This wide range of optional elements indicates a high degree of personalization entrusted with writers. Among the recorded ten elements, "Endorsing the value of the service", "Background information" and "Soliciting responses" account for the highest frequency rate of between $50 \%$ and $60 \%$ of the total corpus. While the first two elements provide readers with information about entry requirements and some facts surrounding the topics, the last element is mostly used to maintain a connection between the writer and the reader.

Reiteration is frequently used in online course descriptions, with half of the recorded elements being reiterative as follows: "Establishing credentials", "Selling point", "Background information", "Ensuring teaching quality", "Endorsing the value of the service", "Describing the service", "Soliciting responses" and "Indicating the value of the service". The prevalence of repeating different elements with different goals signifies the important cyclicity of both communicative purposes: informative (essential information about the course) and promotional (promising the course quality, the course instructor and encouraging learners to register).

\section{Answers to the research question}

\subsection{What is the generic structure potential of the course description?}

The generic structure potential of forty course descriptions from faculty $\mathrm{Y}$ of University and online platform $\mathrm{A}$ is described below.

\section{Figure 3}

GSP of Course Description

$$
\begin{aligned}
& \cap \quad \Omega \quad \cap \Omega \\
& \{(\mathrm{BI} \bullet)(\mathrm{EC} \bullet)(\mathrm{SP} \bullet)\}\left(\mathrm{T}^{\bullet}\right)(\mathrm{E} \bullet)(\mathrm{A} \bullet)(\mathrm{S})(\mathrm{EQ} \bullet)\left(\mathrm{I}^{\bullet}\right) \mathrm{D}^{\bullet}
\end{aligned}
$$

The round brackets indicate the optionality of elements, which means that the following elements are optional: BI, EC, SP, T, E, A, S, $\mathrm{EQ}$ and I. The lack of accompaniment of round 
brackets indicates the obligatory status of element D. The dot next to an element shows that this element is typically expressed in a number of sentences instead of solely a single clause or sentence. This means that all elements, except element $S$ are in the form of paragraphs. The curved arrow $\curvearrowleft$ symbolizes repetition, which shows that elements E, EQ, D and I may appear for more than once in the text. The modest number of available elements and the negligence of promotional aspect also indicates many times and at different locations throughout a description. On the other hand, the curved arrow accompanied by braces $\Omega$ \} shows the equal quality of repetition, which means if BI occurs twice, so does EC and SP.

The inclusion of a total of ten elements in the generic structure shows a diverse amount of information, namely "Describing the service", "Background information", "Topic centrality", "Endorsing the value of the service". Among these elements, solely "Describing the service" emerges as being obligatory to the course description. Its status corresponds with the findings from research into university brochures (Osman, 2008) and international students' prospectus (Askehave, 2007), when it also appeared in every text of the corpus. Therefore, it can be concluded a brief description of the service is of utmost important to the academicpromotional genre.

Elements with promotional values such as "Establishing credentials", "Selling point", "Ensuring teaching quality", "Soliciting responses", and "Addressing needs" are also utilized extensively. Each of these elements is employed as a different approach for promoting the course. While "Ensuring teaching quality" and "Selling point" focus on ensuring the high quality of the course content and activities, "Establishing credentials" places emphasis on the instructors' qualifications and professional experience. The "Addressing needs" and "Soliciting responses", on the other hand, point towards the available demand from students and develop a conversation between learners and description writers. Among these five elements, "Ensuring teaching quality" and "Selling point" are most commonly used. While the element "Selling point" is a novel element compared to the previous research, the "Ensuring teaching quality" element has been found when analysing the "Why choose us?" section in university websites (Yang, 2013).
Commonly, this element is employed to introduce and guarantee the high teaching and learning quality of course providers and academic institutions, thus convincing students to enroll in the course.

Based on the above findings, it can be concluded that a course description mostly consists of information about the course content and targeted learners, proving its primary function as informative. The promotional goal is achieved through a range of communicative media, yet it does not serve as the main goal of the course description.

\subsection{How are the generic structure potential of the conventional university course descriptions different from that of the online course descriptions?}

The generic structure potential of the course description from faculty $\mathrm{Y}$ of University $\mathrm{X}$ is displayed below.

\section{Figure 4}

GSP of Traditional Course Description

$$
\begin{gathered}
\cap \\
(\mathrm{BI} \bullet)\{\mathrm{D} \bullet[(\mathrm{T} \bullet) \bullet(\mathrm{I})]\} \bullet(\mathrm{E} \bullet)
\end{gathered}
$$

The pattern shows a total of five elements, including one obligatory element and four optional elements. It can be seen that informative elements dominate this generic structure, signaling the primary informative goal of the traditional course description. The modest number of available elements and the negligence of the promotional aspect also indicate the content-oriented and concise nature of the traditional course description, which corresponds with the course description writing guidelines from some universities and colleges (Stanford University, n.d..; Mohawk College, n.d.).

Solely, the element "Describing the service" is compulsory to achieve the communicative goal. A noticeable pattern is the flexible positions of each element with limited constraints. Therefore, it can be concluded that the informative goal is achieved to a certain extent. The absence of promotional elements can be detected in traditional course descriptions, which corresponds with the recorded negligence of Asian publicly-owned educational institutions to using promotional 
literature in their products, especially in the globalizing Higher Education market (Mok, 2003; Osman, 2006; Teo, 2007).

\section{Figure 5}

GSP of Online Course Description
Displayed below is the generic structure potential of the course description from platform A.
$\Omega$

$(\mathrm{DU} \bullet)(\mathrm{OI} \bullet)\{(\mathrm{EC} \bullet)(\mathrm{SP} \bullet)(\mathrm{BI} \bullet)\}$

The generic pattern shows that the online course description contains thirteen generic elements with three obligatory elements and ten optional ones. The dominance of promotional elements indicates a novel approach that description writers can take to attract more students to their courses. However, the seemingly balance between promotional and informative elements in the obligatory elements recorded suggests the mixed goal of online descriptions: introducing the course while encouraging students' enrollment at the same time.

Apparently, the number of incorporated elements in the online course description outnumbers that in the online course description. The wide range of available elements indicates the diverse set of information that an online description is obliged to convey. In addition, compared to the sole presence of one obligatory element in the formal course description, the availability of three obligatory elements namely "Ensuring teaching quality" (a promotional element), "Describing the service" and "Indicating the value of the service" (two informative elements) proves the importance of combining the informative and promotional goal. The demand for dual communicative purposes is reasonable since the branding process is crucial for online course instructors. On the contrary, this process, which describes the demand for marketing and promoting oneself, is not prevalent in public institutions as their reputation has already been earned through history (Wernick, 1991).

Another notable pattern of these descriptions is the number of elements reflecting the description writer's emotions and perspectives such as "Demonstrating understanding", "Establishing credentials", "Claims" and "Addressing needs". The presence of elements carrying personal thoughts shows that the writer is given an extensive range of freedom and creativity to express themselves and establish a reciprocal communication between writers and readers. However, it should be noted that among these elements, the element "Claims", which seemingly shows the writers' ideas most directly, is usually accompanied by sentences with factual information. This sequence is also found in the research into entrepreneurial research articles (Osat, 2012) when element "Claims" only occurred after all the previous studies, the supporting and opposing viewpoints have been reviewed.

The most interesting finding is that the available elements in the online course introduction seemingly correspond with the customers' purchase decision-making process by Armstrong and Kotler in 2018.

\section{Figure 6}

Buyer-Readiness Stages (Armstrong \& Kotler, 2018, p. 432)

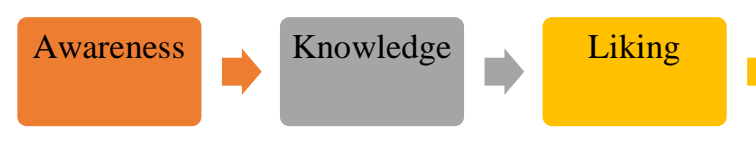

The process begins with "Awareness" when customers acknowledge the presence of the course and identify their needs (with element "Indicating the value of the service"), followed

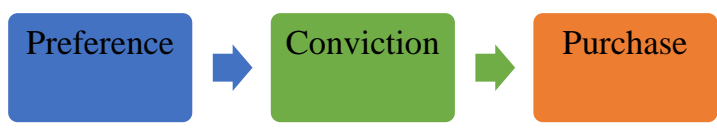

by "Knowledge" when they gain essential information about the course thanks to informative elements such as "Background information", "Describing the service". Next, in 
the "Liking" stage, customers gain insights into the background of the topic and the course content, thus develop interest in the course with "Topic centrality" and "Endorsing the value of the course". The "Preference" and "Conviction" stages are where promotional elements exert their dominance when they provide potential learners with promises of teaching quality, credibility of the course instructors ("Ensuring teaching quality", "Establishing credentials") and recognition of feelings, needs and demands ("Demonstrating understanding", "Addressing needs"). Customers are compelled to register for the course when they are ensured consistently of their suitability for the course ("Indicating the value of the service") and have taken under consideration the unique points of the course compared to others ("Selling point", "Offering incentives"). Generally speaking, this decision-making process of course purchasers bears close resemblance to the steps one tends to take before buying any product.

In conclusion, the distinguishing elements between the formal and online descriptions are as follows.

Firstly, the number of emerging elements in online descriptions outweighs that in formal descriptions (thirteen compared to five). This statistical discrepancy indicates the gap between these two groups in terms of the amount of information to be covered.

Secondly, the major content and communicative purposes of these two groups of descriptions are different. While the formal description focuses on the informative goal, the online course descriptions have dual communicative aims: informative and promotional, thus cover a larger amount of information. All the available elements play their role in the customers' decision-making process and lure them to their purchasing decision.

\section{Conclusion}

The study investigated the generic structure potential of course descriptions and examined the differences between the formal and online course descriptions. From the analysis, it can be concluded that a typical generic structure of a course description consists of ten elements with one obligatory element, namely "Describing the service". Its original informative purpose, which is to provide readers with the major course content and activity, maintains its dominance. The supplementary promotional goal is also added but with restraints. Regarding the difference between formal and online course descriptions, it mainly lies in the amount of information conveyed and their communicative goals. While the former has only five elements to focus on providing the audience with the course content and objectives; the latter includes up to thirteen elements to achieve its dual communicative goals of informing the audience and promoting the course at the same time.

With this study, the researchers hope to provide a source of reference for description writers to elevate the quality of course descriptions and ensure the degree of readability, specifically in the 21 st century, when course description serves as a communicative channel for instructors and learners. The findings can also support students by providing them with a checklist of information to look for when registering for any course.

However, there exist some limitations due to time constraints and limited personnel. Firstly, the corpora are rather small, the modest number of 40 course descriptions in the text cannot persuasively guarantee the representativeness of the corpora. Accordingly an investigation into a larger and more diverse, such as cross-cultural corpora, in future research is likely to generate a more in-depth and comprehensive generic structure of course description. Secondly, the focus of the research is the macrostructure, leaving the microstructure features of course description mostly unexamined. Future research can consider looking into the microstructure or the lexical features of the course descriptions.

\section{References}

Armstrong, G., \& Kotler, P. (2018). Principles of marketing. Pearson Australia.

Askehave, I. (2007). The impact of marketization on higher education genres - the international student prospectus as a case in point. Discourse Studies, 9(6), 723-742. https://doi.org/10.1177/1461445607082576

Bawarshi, A. S., \& Reiff, M. J. (2010). Genre: An introduction to history, theory, research, and pedagogy. Parlor Press.

Bhardwa, S. (2018, March 27). Students place higher value on course content when choosing a university. Timer higher education. https://www.timeshighereducation.com/student/news/s 
tudents-place-higher-value-course-content-whenchoosing-university

Bhatia, V. K. (1997). Genre-mixing in academic introductions. English for Specific Purposes, 16(3), 181195. https://doi.org/10.1016/s0889-4906(96)00039-7

Bhatia, V. K. (2002). Applied genre analysis: A multiperspective model. Ibérica, 4, 3-19.

Borzovs, J., Niedrite, L., \& Solodovnikova, D. (2016). Strategies to reduce attrition among first year computer science students. In M. M. Pinheiro \& D. Simões (Eds.), Handbook of research on engaging digital natives in higher education settings (pp. 98-120). IGI Global.

Bożykowski, M., Izdebski, A., Jasiński, M., KoniecznaSałamatin, J., Zając, T., \& Styczeń, M. (2014). Educational and occupational progression - following graduates from the University of Warsaw. Edukacja, 6(131), 23-38.

Callaghan, M., Knapp, P., \& Noble, G. (1993). Genre in practice. In B. Cope \& M. Kalantzis (Eds.), The powers of literacy: A genre approach to teaching writing. The Falmer Press.

Chapman, M. L. (1994). The Emergence of Genres. Written Communication, $11(3), \quad 348-380$. https://doi.org/10.1177/0741088394011003003

Coe, R., \& Freedman, A. (1988). Genre theory: Australian and North American approaches. In M. L. Kennedy (Ed.), Theorizing composition: A critical sourcebook of theory and scholarship in contemporary composition studies (pp. 136-147). Greenwood Publishing Group.

Dudley-Evans, T. (1994). Genre analysis: An approach to text analysis for ESP. In M. Coulthard (Ed.), Advances in Written Text Analysis (pp. 219-228). Routledge.

Fairclough, N. (1995). Critical discourse analysis: The critical study of language. Pearson Education Limited.

Gibson K., \& Walters J. (2002). Access and guidance in tutor-student relationships. Journal of Access and Credit Studies, 4(1), 20-31.

Halliday, M. A. K. (1978). Language as social semiotic: The social interpretation of language and meaning. Arnold.

Halliday, M. A. K., \& Hasan, R. (1989). Language, context, and text: Aspects of language in a socialsemiotic perspective. Oxford University Press.

Hasan, R. (1979). On the notion of text. In J. S. Petofi (Ed.), Text vs sentence: Basic questions of textlingusitics (Vol. 2, pp. 369-390). Helmet Buske.

Hasan, R. (1984). The nursery tale as a Genre. Nottingham Linguistic Circular, 13, 71-102.

Hyland, K. (2002). Genre: Language, Context, And Literacy. Annual Review of Applied Linguistics, 22, 113-135. https://doi.org/10.1017/s0267190502000065

Hyon, S. (1996). Genre in three traditions: Implications for ESL. TESOL Quarterly, 30(4), 693-722. https://doi.org/10.2307/3587930

Johns, A. M. (2012). Genre and ESL/EFL composition instruction. In B. Kroll (Ed.), Exploring the dynamics of second language writing (pp. 195217). Cambridge University Press. https://doi.org/10.1017/cbo9781139524810.014

Knapp, P., \& Watkins, M. (1994). Context - text - grammar: Teaching the genres and grammar of school writing in infants and primary classrooms. Text Productions.
Kuh, G. D., Kinzie, J., Buckley, J. A., Bridges, B. K., \& Hayek, J. C. (2006). What matters to student success: A review of the literature. Commissioned report for the National Symposium on postsecondary student success: Spearheading a dialog on student success. National Postsecondary Education Cooperative.

Kwong, J. (2000). Introduction: Marketization and privatization in education. International Journal of Educational Development, 20(2), 87-92. https://doi.org/10.1016/s0738-0593(99)00060-7

Maringe, F. (2006). University and course choice: Implications for positioning, recruitment and marketing. International Journal of Educational Management, 20(6), 466-479. https://doi.org/10.1108/09513540610683711

Martin, J. R. (1984). Language, register and genre. In F. Christie (Ed.), Children's writing: Reader (pp. 21-30). Deakin University Press.

Martin, J. R., Christie F., \& Rothery J. (1987). Social processes in education: A reply to Sawyer and Watson (and others). In I. Reid (Ed.), The place of genre in learning: Current debates (pp. 58-82). Deakin University Press.

Mautner, G. (2005). The entrepreneurial University: A discursive profile of a higher education buzzword. Critical Discourse Studies, 2(2), 95-120. https://doi.org/10.1080/17405900500283540

Mohawk College. (n.d.). How to write a course description. https://www.mohawkcollege.ca/employees/centre-forteaching learning/curriculum-development/how-to-writea-course-description

Mok, K. H. (2003). Globalisation and higher education restructuring in Hong Kong, Taiwan and Mainland China. Higher Education Research \& Development, 22(2), 117-129. https://doi.org/10.1080/07294360304111

Osat, F. N. (2012). Generic structure of introductions in entrepreneurship research articles [Unpublished master's thesis]. University of Malaya Kuala Lumpur.

Osman, H. (2006). An investigation of socio-cognitive strategies in university brochures. ESP Malaysia, 12, 39-51.

Osman, H. (2008). Re-branding academic institutions with corporate advertising: A genre perspective. Discourse \& Communication, 2(1), 57-77. https://doi.org/10.1177/1750481307085577

Paltridge, B. (1993). Writing up research: A systemic functional perspective. System, 21(2), 175-192. https://doi.org/10.1016/0346-251x(93)90040-n

Stanford University. (n.d.). What is a course description? https://registrar.stanford.edu/staff/courses-schedulingand-bulletin/courses/what-course-description

Swales, J. (1990). Genre analysis: English in academic and research settings. Cambridge University Press.

Teo, P. (2007). The marketisation of higher education: A comparative case-study of two universities in Singapore. Critical Approaches to Discourse Analysis across Disciplines, 1(1), 95-111. http://hdl.handle.net/10497/4674

Wernick, A. (1991). Promotional culture: advertising, ideology, and symbolic expression (Theory, Culture \& Society). Sage Publications, Inc. https://doi.org/10.1007/978-1-349-22346-6_17

Yang, W. (2013). 'Why choose us?' texts in university websites: A genre analysis. Taiwan International ESP Journal, 5(1), 45-80. 
Yorke, M. (1999). Leaving early: Undergraduate noncompletion in higher education. Falmer Press.

Yunick, S. (1997). Genres, registers and sociolinguistics. World Englishes, 16(3), 321-336. https://doi.org/10.1111/1467-971x.00067.

\section{APPENDIX 1: Source of online data}

The online course provider platform, Udemy, was named A in this study.

Website: https://www.udemy.com/

\section{APPENDIX 2: Examples of elements found in the corpus}

\begin{tabular}{|c|c|c|c|c|}
\hline No. & Elements & Description & Example & Short forms \\
\hline 1 & $\begin{array}{l}\text { Welcoming } \\
\text { remark }\end{array}$ & $\begin{array}{l}\text { Refers to the welcoming } \\
\text { message from the course } \\
\text { instructor }\end{array}$ & $\begin{array}{l}\text { Hello and welcome to Military History of } \\
\text { the Classical Greek World. }\end{array}$ & W \\
\hline 2 & $\begin{array}{l}\text { Background } \\
\text { information }\end{array}$ & $\begin{array}{l}\text { Introduces some general } \\
\text { knowledge about the } \\
\text { course content }\end{array}$ & $\begin{array}{l}\text { Southeast Asia is a historical and cultural } \\
\text { region, distinct from the two great cultures } \\
\text { of the East -India and China. }\end{array}$ & BI \\
\hline 3 & $\begin{array}{l}\text { Topic } \\
\text { centrality }\end{array}$ & $\begin{array}{l}\text { Emphasizes the } \\
\text { importance of the taught } \\
\text { content }\end{array}$ & $\begin{array}{l}\text { Understanding how to effectively } \\
\text { communicate cross-culturally, is more } \\
\text { important today than ever before! }\end{array}$ & $\mathrm{T}$ \\
\hline 4 & $\begin{array}{l}\text { Indicating a } \\
\text { gap }\end{array}$ & $\begin{array}{l}\text { Points out the lack of the } \\
\text { taught content in the } \\
\text { standard educational } \\
\text { curriculum }\end{array}$ & $\begin{array}{l}\text { And here is the truth most people don't } \\
\text { know about: } \\
\text { "Knowing facts is NOT the same as } \\
\text { having knowledge, understanding and } \\
\text { ability". } \\
\text { What you mostly get by following the } \\
\text { news are the simple facts of what happens, } \\
\text { when, and who is involved. }\end{array}$ & IG \\
\hline 5 & Claim & $\begin{array}{l}\text { Refers to the writer's } \\
\text { evaluation of the } \\
\text { presented situation or } \\
\text { fact }\end{array}$ & $\begin{array}{l}\text { Most likely, they have training and } \\
\text { practice. }\end{array}$ & $\mathrm{CA}$ \\
\hline 6 & $\begin{array}{l}\text { Establishing } \\
\text { credentials }\end{array}$ & $\begin{array}{l}\text { Focuses on the course } \\
\text { instructor's } \\
\text { qualifications (e.g, } \\
\text { working experience, } \\
\text { successful students, } \\
\text { awards, etc.) }\end{array}$ & $\begin{array}{l}\text { ABOUT THE INSTRUCTOR } \\
\text { Shani Raja is a veteran journalist who has } \\
\text { edited for The Wall Street Journal } \\
\text { and contributed to The Economist, } \\
\text { the Financial Times, and Bloomberg } \\
\text { News, among other top news } \\
\text { organisations. He has trained dozens } \\
\text { of prominent journalists in the craft of } \\
\text { writing, including at The Wall } \\
\text { Street Journal. Shani's flagship } \\
\text { course, Writing With Flair, has long } \\
\text { been the bestselling writing course on } \\
\text { Udemy, with many tens of thousands of } \\
\text { passionate students learning how to } \\
\text { become elite writers. }\end{array}$ & $\mathrm{EC}$ \\
\hline 7 & $\begin{array}{l}\text { Ensuring } \\
\text { teaching } \\
\text { quality }\end{array}$ & $\begin{array}{l}\text { Describes the teacher- } \\
\text { responsibility-related } \\
\text { elements that will } \\
\text { contribute to a } \\
\text { motivating learning } \\
\text { environment }\end{array}$ & $\begin{array}{l}\text { I designed this course as a series of clear, } \\
\text { non-jargon laden video lectures and texts }\end{array}$ & EQ \\
\hline 8 & $\begin{array}{l}\text { Indicating the } \\
\text { value of the } \\
\text { service }\end{array}$ & $\begin{array}{l}\text { Refers to the entry } \\
\text { requirements, fees and } \\
\text { duration of the course }\end{array}$ & $\begin{array}{l}\text { There is no prerequisite other than a good } \\
\text { command of English. }\end{array}$ & I \\
\hline
\end{tabular}

Zając, T. Z., \& Komendant-Brodowska, A. (2018). Premeditated, dismissed and disenchanted: Higher education dropouts in Poland. Tertiary Education Management, 25, 1-16. https://doi.org/10.1007/s11233-018-09010-z 


\begin{tabular}{|c|c|c|c|c|}
\hline 9 & $\begin{array}{l}\text { Endorsing the } \\
\text { value of the } \\
\text { service }\end{array}$ & $\begin{array}{l}\text { Refers to statements } \\
\text { describing the course } \\
\text { objectives }\end{array}$ & $\begin{array}{l}\text { This course is designed to help students to } \\
\text { develop an understanding of the } \\
\text { fundamentals of English pragmatics and } \\
\text { understanding of the fundamentals of } \\
\text { English pragmatics and skills in pragmatic } \\
\text { analysis. }\end{array}$ & $\mathrm{E}$ \\
\hline 10 & $\begin{array}{l}\text { Describing the } \\
\text { service }\end{array}$ & $\begin{array}{l}\text { Refers to statements } \\
\text { about the course content } \\
\text { and the teaching and } \\
\text { learning methods }\end{array}$ & $\begin{array}{l}\text { The course will systematically introduce } \\
\text { students to some key concepts in the } \\
\text { domains of pragmatics, discourse analysis, } \\
\text { language acquisition, sociolinguistics, etc. } \\
\text { and help them achieve an overview of the } \\
\text { fundamental aspects of Applied } \\
\text { Linguistics. }\end{array}$ & $\mathrm{D}$ \\
\hline 11 & $\begin{array}{l}\text { Offering } \\
\text { attractive } \\
\text { incentives }\end{array}$ & $\begin{array}{l}\text { Describes the financial } \\
\text { support or reward- } \\
\text { related elements which } \\
\text { motivate students to } \\
\text { apply }\end{array}$ & $\begin{array}{l}\text { You'll also get a free ebook to guide you } \\
\text { in the course. }\end{array}$ & $\mathrm{OI}$ \\
\hline 12 & $\begin{array}{l}\text { Soliciting } \\
\text { responses }\end{array}$ & $\begin{array}{l}\text { Ends the description } \\
\text { with invitations for } \\
\text { enrolment or further } \\
\text { questions about the } \\
\text { course }\end{array}$ & $\begin{array}{l}\text { I invite you to send me a message if you } \\
\text { have any questions about the content of } \\
\text { this course. }\end{array}$ & $\mathrm{S}$ \\
\hline 13 & $\begin{array}{l}\text { Closing } \\
\text { remark }\end{array}$ & $\begin{array}{l}\text { Refers to the last few } \\
\text { words from the course } \\
\text { descriptor to end the } \\
\text { description }\end{array}$ & $\begin{array}{l}\text { Thanks for having a look! } \\
\text {-bl }\end{array}$ & $\mathrm{C}$ \\
\hline 14 & $\begin{array}{c}\text { Social } \\
\text { expectation }\end{array}$ & $\begin{array}{l}\text { Describes the course } \\
\text { expectation to certain } \\
\text { groups of students }\end{array}$ & $\begin{array}{l}\text { Students of an honours program are } \\
\text { entrusted with more flexibility and } \\
\text { responsibility in course activities. }\end{array}$ & $\mathrm{SE}$ \\
\hline 15 & Selling point & $\begin{array}{l}\text { Refers to promises of } \\
\text { exceptional outcome } \\
\text { from the description } \\
\text { writer }\end{array}$ & $\begin{array}{l}\text { Your leadership abilities will expand } \\
\text { dramatically ... }\end{array}$ & SP \\
\hline 16 & $\begin{array}{l}\text { Demonstrating } \\
\text { understanding }\end{array}$ & $\begin{array}{l}\text { Describes the expected } \\
\text { audience's reaction to } \\
\text { the taught content }\end{array}$ & $\begin{array}{l}\text { Do you need to write a literary analysis or } \\
\text { participate in a book discussion, but you } \\
\text { don't know where to start? }\end{array}$ & DU \\
\hline 17 & $\begin{array}{l}\text { Addressing } \\
\text { needs }\end{array}$ & $\begin{array}{l}\text { Outlines specific types } \\
\text { of students with } \\
\text { different needs }\end{array}$ & $\begin{array}{l}\text { Even if you're not interested in } \\
\text { demonstrating mastery... }\end{array}$ & A \\
\hline
\end{tabular}




\title{
TIỀM NĂNG CẤU TRÚC THỂ LOẠI CỦA BẢN GIỚI THIỆU MÔN HỌC
}

\author{
Hồ Tường Thanh ${ }^{1}$, Nguyễn Thị Minh Tâm² \\ 1. Khoa Su phạm tiếng Anh, Truoòng Đại học Ngoại ngũ, ĐHQGHN, \\ Phạm Văn Đồng, Cầu Giấy, Hà Nọi, Việt Nam \\ 2. Khoa Ngôn ngũ và Văn hóa các nuớc nói tiếng Anh, Truờng Đại học Ngoại ngũ., ĐHQGHN, \\ Phạm Văn Đồng, Cầu Giấy, Hà Nội, Việt Nam
}

\begin{abstract}
Tóm tắt: Tiềm năng cấu trúc thể loại (GSP) là "một chuỗi các cấu trúc văn bản (textual structures) có mặt trong một thể loại văn bản" (Hasan, 1984, tr. 79) và được xây dựng nhằm đáp ứng yêu cầu phải có "cấu trúc thể loại" của văn bản, từ đó có cái nhìn tổng quan về một thể loại (Halliday, 1978). Mặc dù đã có nhiều nghiên cứu về các thể loại văn bản học thuật và quảng cáo, chưa có nhiều nghiên cứu đề cập đến bản giới thiệu môn học. Nghiên cứu này tập trung vào xây dựng tiềm năng cấu trúc thể loại của bản giới thiệu môn học và tìm ra sự khác nhau giữa bản giới thiệu môn học truyền thống và bản giới thiệu môn học trực tuyến dựa trên một khung phân tích gồm 14 thành tố. Nghiên cứu tìm ra thêm 4 thành tố chưa xuất hiện khung phân tích gốc. Quan trọng hơn cả, nghiên cứu phát hiện thấy bản giới thiệu môn học tập trung vào mục tiêu chính là cung cấp thông tin cho người đọc, còn mục tiêu quảng cáo chỉ là phụ. Về sự khác biệt giữa hai hình thức, bản giới thiệu môn học trực tuyến chứa nhiều thành tố quảng cáo hơn, mặc dù vẫn tập trung vào cả hai mục tiêu. Ngược lại, bản giới thiệu môn học truyền thống tập trung vào mục tiêu cung cấp thông tin và gần như bỏ qua yếu tố quảng cáo.
\end{abstract}

Từ khóa: tiềm năng cấu trúc thể loại, giới thiệu môn học, khóa học truyền thống, khóa học trực tuyến 